Ján SLOTA

Miroslav JURČIŠIN

Technical University of Košice, Slovakia

\title{
EXPERIMENTAL AND NUMERICAL PREDICTION OF SPRINGBACK IN V-BENDING OF ANISOTROPIC SHEET METALS FOR AUTOMOTIVE INDUSTRY
}

\begin{abstract}
Springback is a common phenomenon in sheet metal forming, caused by the elastic redistribution of stresses during unloading. It has been recognized that springback is essential for the design of tools used in sheet metal forming operations. A finite element method (FEM) code has been used to analyze the sheet metals V-bending process. In the work, three types of steels TRIP, AHSS and mild steel were used. Normal anisotropic material behavior has been considered. A contact algorithm for arbitrarily shaped rigid tools has been realized by means of accurate approach. This paper describes a robust method of predicting springback under bending and unbending of sheets. Constitutive models, aimed at predicting the final shape of the sheet after the springback by varying the setting of the operational parameters of the forming process, were discussed. The accuracy of the model was verified by comparison with results of PAM-STAMP 2G package and experimental results.
\end{abstract}

Keywords: air bending, springback, plastic anisotropy, numerical modellling

\section{Introduction}

In the bending technology it is difficult to achieve accurate and repeatable angle of a bend. This problem is caused by elastic springback, which is considerable in processes of sheet metal forming [1-4]. Springback in processes of sheet metal forming causes troubles in assembling processes, because springback entails anomaly of required shape of the part. Economical aspect of problems associated with springback is in the USA solely in the sphere of automotive industry estimated on the 50 million dollar per year [5]. Springback is defined as a dimensional change of a shape after releasing a tool due to elastic effects [6]. In the past, handy tables [7, 8] or graphs [9] were the traditional ways used for prediction of springback. For this purpose, today are frequently used FE codes, which provide numerical simulations of sheet metal forming processes. PAM-STAMP 2G, Autoform, DYNAFORM and more codes belong to the group of software which are used for numerical simulations of sheet metal forming processes. Several parameters influence on the amount of springback. 
Several studies have shown, that the amount of springback is influenced by factors such as dimension of the blank, thickness of the blank, the tool shape, the tool radius and more $[10,11]$. Except these technological variables, material properties as for example yield stress, the Young's modulus, the Bauschinger effect, constitutive behavior in plastic field also influence on the amount of springback [12-14]. Additional studies confirmed that a normal anisotropy of the material has also influence on the springback amount [15]. Accuracy of the numerical simulation is associated with the defining of input data, esspecially with the definition of yield function and hardening curve. Early developed material models as Tresca or von Misses were developed according to parameters obtained from the simple tensile test. These material models were soon insufficient to obtain accurate results of numerical simulation, because they did not describe several parameters of material behavior. They did not describe anisotropy of materials, kinematic hardening etc. [16, 17]. In experimental part of this work, Hollomon hardening curve was used. The Hollomon hardening law is defined as follows [18]:

$$
\sigma_{P}=C \varepsilon^{n}
$$

where: $C$ - material constant,

$n$-index of deformation hardening,

$\varepsilon-$ total strain.

Another curve of hardening which was used is hardening curve defined by Krupkowsky [19]:

$$
\sigma_{p}=C\left(\varepsilon_{P}+\varepsilon_{0}\right)^{n}
$$

where: $\varepsilon_{p}$ - plastic strain,

$$
\varepsilon_{0} \text { - offset strain. }
$$

The last used hardening curve was defined by Bergström-van Liempt [20]:

$$
\sigma_{y}(\bar{\varepsilon})=\sigma_{0}+\Delta \sigma_{m} \cdot\left[\beta \cdot\left(\bar{\varepsilon}+\varepsilon_{0}\right)-e^{-\Omega \cdot\left(\bar{\varepsilon}+\varepsilon_{0}\right)}\right]^{n^{\prime}}+\sigma_{0}^{*} \cdot\left[1+\frac{k T}{\Delta G_{0}} \cdot \ln \left(\frac{\dot{\varepsilon}}{\dot{\varepsilon}_{0}}\right)\right]^{m^{\prime}}
$$

where notation can be find in the relevant literature [20].

In this work, the definition of Bergström-van Liempt hardening curve was set by TataSteel Europe company, due to fact that the material model was acquired from the mentioned company. Graphical illustration of used hardening curves is shown in the Fig. 1a. Hill 48, Hill 90, Vegter and Barlat yield functions in numerical simulation of springback were used. Description of Vegter material model is very difficult, because it is necessary to perform mechanical tests for 
four different strain modes, and use Bezier interpolation [20-23]. Comparisons of yield functions are shown in Fig. 1b. Stress-strain diagram of used steels illustrates Fig. 2.

a)

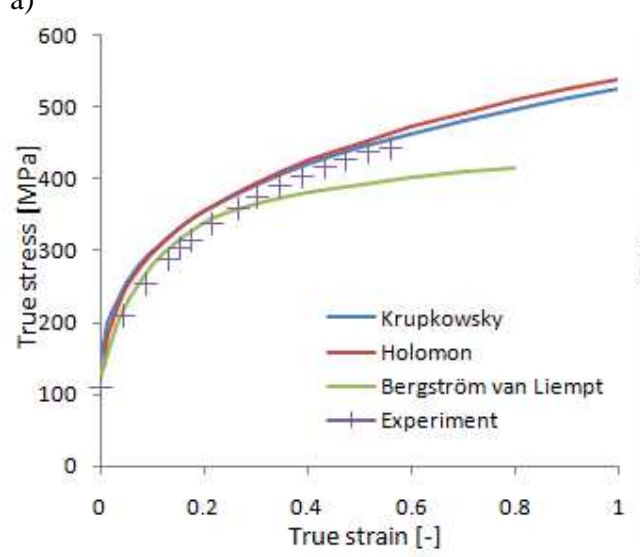

b)

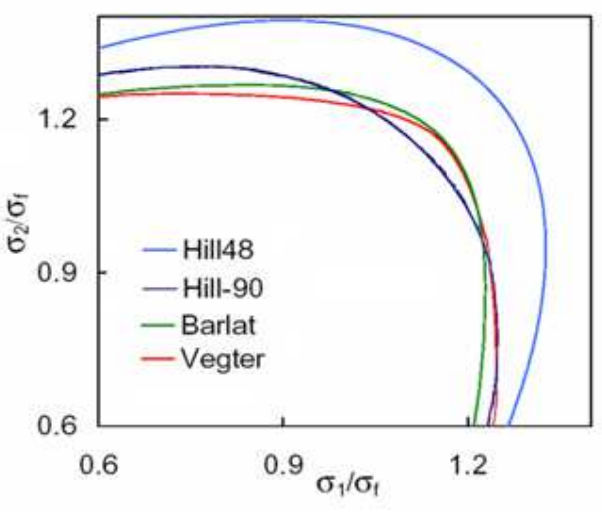

Fig.1. Comparison of used hardening curves (a) and different yield functions (b) for mild steel

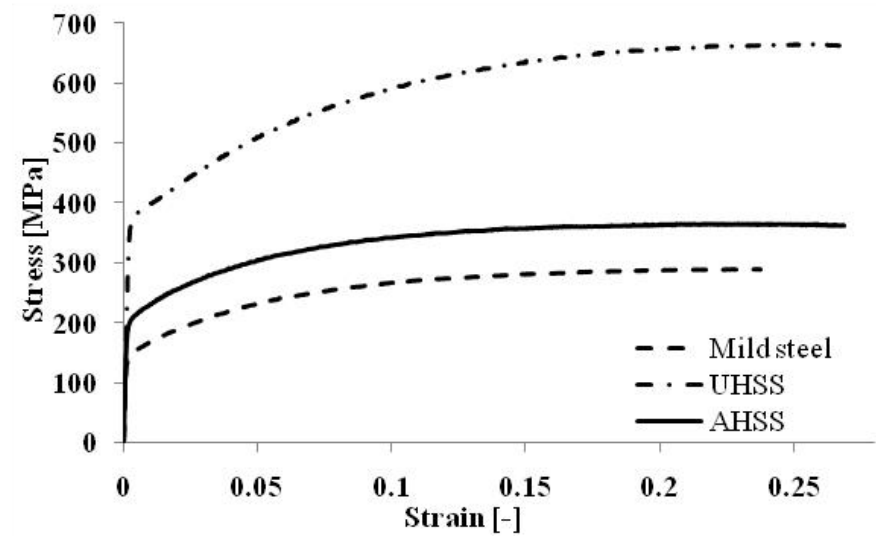

Fig. 2. Stress-strain diagram of used steels

Three different categories of steel were used in experimental part of this work. One of these is a TRIP steel, which has significantly greater springback. It is caused by high work hardening of this material. Therefore, there may be problem in the production line, or in an accurate results of FEM in case of springback prediction. In different studies [24, 25] authors highlighted the importance of work hardening and its influence on the springback amount and 
discuss about more accurate material description, for example mixed work hardening [24]. Considering this, several hardening curves and yield functions were used in this paper.

\section{Objectives and approach}

Experiment of bending sheet metal strips focused on the measuring of the springback amount was performed. This process was subsequently simulated in PAM-STAMP 2G software. Before description of particular parts of experiment it is necessary to define properties of used steels, final shape, tool geometry, parameters of used machine and the conditions of the process. As was mentioned, in experimental part of this work three different categories of steel were used: AHSS - H220PD, UHSS - TRIP RAK 40/70 and mild steel - DC06 (Table 1). Five sheet metal strips from each type of steel were cut.

Table 1. Thicknesses of used materials

\begin{tabular}{|c|c|c|}
\hline Category & Type & Thickness [mm] \\
\hline AHSS & H220PD & 0.8 \\
\hline UHSS & TRIP RAK 40/70 & 0.75 \\
\hline Mild Steel & DC06 & 0.85 \\
\hline
\end{tabular}

Measuring of mechanical properties of materials was carried out using samples which were cut in directions $0^{\circ}, 45^{\circ}$ and $90^{\circ}$ to the rolling direction. The test rod of the length $80 \mathrm{~mm}$ according to the ISO 6892-1: 2009 was used. Tests were performed on the machine Tiratest 2300 . Tables 2-5 show data necessary to define Hill 48 and Hill 90 material models. Vegter material model for mild steel and AHSS was set by the TataSteel Europe Company. In the case of defining Barlat material model it is necessary to define yield stress and Lankford coefficient of normal anisotropy $r$. These values are shown in Table 3. During defining Barlat material model, weight of each Lankford coefficient of anisotropy in three directions to the rolling directions are necessary to define. This parameter for each coefficient was set to 1 , because the weights of measurement in these directions had the same relevance.

Table 2. Mechanical properties of AHSS - H220PD

\begin{tabular}{|c|c|c|c|c|c|c|}
\hline $\begin{array}{c}\text { Specimen } \\
\text { orientation }\end{array}$ & $\begin{array}{c}\boldsymbol{R}_{\boldsymbol{p} \mathbf{0 . 2}}(\boldsymbol{R e}) \\
{[\mathbf{M P a}]}\end{array}$ & $\begin{array}{c}\boldsymbol{R}_{\boldsymbol{m}} \\
{[\mathbf{M P a}]}\end{array}$ & $\begin{array}{c}\boldsymbol{A}_{\mathbf{8 0}} \\
{[\mathbf{\%}]}\end{array}$ & $\boldsymbol{n}$ & $\begin{array}{c}\boldsymbol{C} \\
{[\mathbf{M P a}]}\end{array}$ & $\boldsymbol{r}$ \\
\hline $0^{0}$ & 219 & 385 & 34.5 & & & 1.172 \\
\hline $45^{0}$ & 225 & 368 & 37.4 & 0.231 & 648.6 & 1.782 \\
\hline $90^{0}$ & 238 & 383 & 35.8 & & & 1.823 \\
\hline
\end{tabular}


Table 3. Mechanical properties of UHSS -TRIP RAK 40/70

\begin{tabular}{|c|c|c|c|c|c|c|}
\hline $\begin{array}{c}\text { Specimen } \\
\text { orientation }\end{array}$ & $\begin{array}{c}\boldsymbol{R}_{\boldsymbol{p 0 . 2}}(\boldsymbol{R e}) \\
{[\mathbf{M P a}]}\end{array}$ & $\begin{array}{c}\boldsymbol{R}_{\boldsymbol{m}} \\
{[\mathbf{M P a}]}\end{array}$ & $\begin{array}{c}\boldsymbol{A}_{\mathbf{8 0}} \\
{[\%]}\end{array}$ & $\boldsymbol{n}$ & $\begin{array}{c}\boldsymbol{C} \\
{[\mathbf{M P a}]}\end{array}$ & $\boldsymbol{r}$ \\
\hline $0^{\circ}$ & 442 & 771 & 27.7 & & & 0.686 \\
\hline $45^{\circ}$ & 441 & 762 & 25.4 & 0.224 & 1330.2 & 0.87 \\
\hline $90^{\circ}$ & 450 & 766 & 25.9 & & & 0.838 \\
\hline
\end{tabular}

Table 4. Mechanical properties of mild steel DC06

\begin{tabular}{|c|c|c|c|c|c|c|}
\hline $\begin{array}{c}\text { Specimen } \\
\text { orientation }\end{array}$ & $\begin{array}{c}\boldsymbol{R}_{\boldsymbol{p 0 . 2}}(\boldsymbol{R e}) \\
{[\mathbf{M P a}]}\end{array}$ & $\begin{array}{c}\boldsymbol{R}_{\boldsymbol{m}} \\
{[\mathbf{M P a}]}\end{array}$ & $\begin{array}{c}\boldsymbol{A}_{\mathbf{8 0}} \\
\boldsymbol{\%}\end{array}$ & $\boldsymbol{n}$ & $\begin{array}{c}\boldsymbol{C} \\
{[\mathrm{MPa}]}\end{array}$ & $\boldsymbol{r}$ \\
\hline $0^{\circ}$ & 145 & 292 & 50.8 & & & 1.888 \\
\hline $45^{\circ}$ & 151 & 298 & 47.9 & 0.254 & 538.54 & 1.464 \\
\hline $90^{\circ}$ & 149 & 290 & 48.0 & & & 2.193 \\
\hline
\end{tabular}

Table 5. Output data of the yield stress from a biaxial test (hydraulic bulge), Young's modulus, density and Poisson's ratio

\begin{tabular}{|c|c|c|c|c|}
\hline Steel & $\boldsymbol{\sigma}_{\boldsymbol{y}}[\mathbf{M P a}]$ & $\boldsymbol{E}[\mathbf{G P a}]$ & $\boldsymbol{\rho}\left[\mathbf{k g} \cdot \mathbf{m m}^{\mathbf{- 3}}\right]$ & $\boldsymbol{v}$ \\
\hline AHSS & 290 & 210 & $7.8 \cdot 10^{-6}$ & 0.3 \\
\hline UHSS & 540 & 210 & $7.8 .10^{-6}$ & 0.3 \\
\hline DC06 & 250 & 210 & $7.8 .10^{-6}$ & 0.3 \\
\hline
\end{tabular}

\section{Real experiment of v-bending} and measuring angle of springback

Specimens were cut and subsequently bent with the hydraulic press ZD40. In order to achieve online transfer of information about measured force between the punch and the die, a force sensor has been located on the machine. The scale was located on the front side of the die, because each measurement was performed graphically.

a)

b)

(1)Die (2)Bent sheetmetal strip(3)Punch (4) Scale
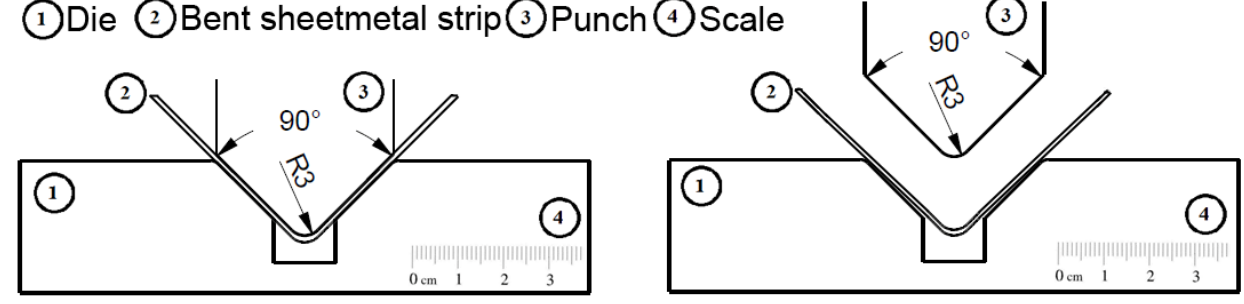

Fig. 3. The Assembly of the die and the punch under the load (a) and after released load (b) 
Principle of measurement is illustrated in Fig. 3. The specimen was located on the die and gradually bent until the closing force of $4 \mathrm{kN}$ was reached. Then, the picture was taken when the tool was released. This kind of graphical measuring method was used due to difficulty of conventional measuring method. It could be assessed that by using graphical method, the springback angle can be calculated and evaluated accurately enough [26].

The graphic software was used for measuring angle changes of specimen arms. Angles were measured only in the unloaded state, because it is apparently that the arms of specimen in loaded state form an angle $90^{\circ}$. This manner of measuring was applied on each specimen. Several angles of the bent specimen were measured using an analog protractor in order to determine uncertainty of the graphical measurement. The maximum measurement uncertainty was up to $1 \%$.

\section{Simulation of the process}

The process of parameters definition is possible to divide into two large parts. Firstly, the bending process was defined and after that the springback parameters were defined. In this stage it is necessary to take a note that in the bending process the setting, ,pinch test" was used. It means that the tool in final stage of loading will not go over the contact force which can cause a dint in the material. By setting up of springback stage it is necessary to note that explicit calculating type was used. Square elements, with a size of $8.3 \mathrm{~mm}$ were used and the maximum refinement level was set to value 4. Five integration points over the thickness were defined. The smallest size of the element after refinement was $1.2 \mathrm{~mm}$. Refinement of elements is shown in Fig. 4. Accurate contact type with coefficient of friction equals to 0.2 was set. The combinations of material models used in the numerical simulations are shown in Table 6.

Table 6. Combination of used material models

\begin{tabular}{|c|c|c|c|c|c|c|c|}
\hline \multicolumn{8}{|c|}{ Scheme of used material models } \\
\hline Yield function & \multicolumn{2}{|c|}{$\mathrm{H}^{\prime} 48$} & \multicolumn{2}{|c|}{$\mathrm{H}^{\prime} 90$} & \multicolumn{2}{|c|}{ B } & $\mathrm{C}-\mathrm{V}$ \\
\hline Hardening curve & $\mathrm{K}$ & $\mathrm{H}$ & $\mathrm{K}$ & $\mathrm{H}$ & $\mathrm{K}$ & $\mathrm{H}$ & BvL \\
\hline \multirow{3}{*}{ Material } & \multicolumn{6}{|c|}{ AHSS } & AHSS \\
\hline & \multicolumn{6}{|c|}{ UHSS } & DC06 \\
\hline & \multicolumn{6}{|c|}{ DC06 } & \\
\hline
\end{tabular}

where: H'48 - Hill 48, H'90 - Hill 90, B - Barlat, C-V - Corus-Vegter, K - Krupkowsky, $\mathrm{H}$ - Hollomon, BvL - Bergström van Liempt 


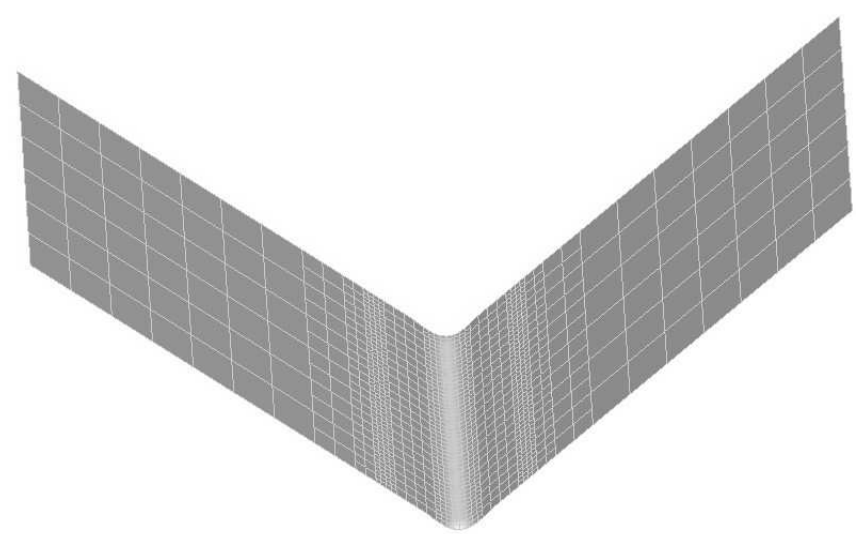

Fig. 4. Illustration of the maximum level of refinement in areas of the greatest stresses.

\section{Results of experiment}

In this chapter, results of experiment and numerical simulations were discussed. The results of simulation and real experiment for specimen made of AHSS with combination of various material models are compared in the Table 8 . Where $\beta_{S}$ is the angle between specimen arms measured in the PAM-STAMP $2 \mathrm{G}, \beta_{M}$ is the angle measured in the real experiment, and $\beta_{D}$ is the absolute value of the deviance between simulation and angle measured in the real experiment. Results in the Table 7 imply, that for prediction of springback of the sheet metal specimens made of AHSS, Hill 90 yield function and Krupkowsky hardening curve together with Hollomon hardening curve are the most accurate. The Hill 48 material model combined with Krupkowsky and Barlat-Krupkowsky hardening curves overestimated the amount of springback, while Hill 48 material model combined with Hollomon, Barlat-Hollomon and Corus-Vegter-Bergström van Liempt hardening curves underestimated the results. The results of simulation and real experiment for specimen made of UHSS with combination of various material models are compared in Table 8.

In this case, the most accurate material model was Hill 90 - Hollomon. For this category of material, Corus-Vegter-Bergström van Liempt material model was not used. All remaining material models, underestimated the amount of springback in comparison with real experiment results. Results of simulation and real experiment using specimen from mild steel DC06 with combination of various material models are compared in Table 9. 
Table 7. Results of simulation and experiment of bending in the transverse direction of AHSS

\begin{tabular}{|c|c|c|c|c|}
\hline \multirow{9}{*}{$\frac{\infty}{2}$} & \multicolumn{4}{|c|}{ Bend in direction transverse to rolling direction } \\
\hline & material model & $\beta_{S}[\mathrm{deg}]$ & $\beta_{M}[\mathrm{deg}]$ & $|\Delta \beta \mathrm{D}|[\mathrm{deg}]$ \\
\hline & Hill 48-Krupkowsky & 1.5 & \multirow{7}{*}{1} & 0.5 \\
\hline & Hill 48-Hollomon & 0.16 & & 0.84 \\
\hline & Hill 90-Krupkowsky & 1.02 & & 0.02 \\
\hline & Hill 90-Hollomon & 0.94 & & 0.06 \\
\hline & Corus-Vegter-Bergström van Liempt & 0.66 & & 0.34 \\
\hline & Barlat-Krupkowsky & 1.74 & & 0.74 \\
\hline & Barlat-Hollomon & 0.74 & & 0.26 \\
\hline
\end{tabular}

Table 8. Results of simulation and experiment of bending in the transverse direction of UHSS

\begin{tabular}{|c|c|c|c|c|}
\hline \multirow{9}{*}{$\begin{array}{l}\boldsymbol{\infty} \\
\frac{\mathbf{n}}{5}\end{array}$} & \multicolumn{4}{|c|}{ Bend in direction transverse to rolling direction } \\
\hline & material model & $\beta_{S}[\mathrm{deg}]$ & $\beta_{M}[\mathrm{deg}]$ & $|\Delta \beta \mathrm{D}|[\mathrm{deg}]$ \\
\hline & Hill 48 - Krupkowsky & 2.51 & \multirow{7}{*}{3.5} & 0.99 \\
\hline & Hill 48 - Hollomon & 2 & & 1.5 \\
\hline & Hill 90 - Krupkowsky & 1.19 & & 2.31 \\
\hline & Hill 90 - Hollomon & 3.48 & & $\mathbf{0 . 0 2}$ \\
\hline & Corus-Vegter-Bergström van Liempt & - & & - \\
\hline & Barlat-Krupkowsky & 1.6 & & 1.9 \\
\hline & Barlat-Hollomon & 1.95 & & 1.55 \\
\hline
\end{tabular}

The most accurate material models for mild steel were yield function described by Barlat, and hardening curve by Hollomon. Material models Hill 48-Krupkowsky and Barlat- Krupkowsky in the small extent overestimated the springback amount, but the difference between the results is acceptable. Hill 48-Hollomon underestimated the springback amount, Corus-Vegter-Bergström van Liempt and Hill 90, in combination with Hollomon and Krupkowsky hardening curve overestimated real springback amount.

Table 9. Results of simulation and experiment of bending in the transverse direction of mild steel

\begin{tabular}{|c|c|c|c|c|}
\hline \multirow{9}{*}{ 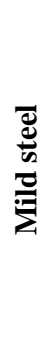 } & \multicolumn{4}{|c|}{ Bend in direction transverse to rolling direction } \\
\hline & material model & $\beta_{S}[\mathrm{deg}]$ & $\beta_{M}[\mathrm{deg}]$ & $|\Delta \beta \mathrm{D}|[\operatorname{deg}]$ \\
\hline & Hill 48-Krupkowsky & 1 & \multirow{7}{*}{0.87} & 0.13 \\
\hline & Hill 48-Hollomon & 0.54 & & 0.33 \\
\hline & Hill 90-Krupkowsky & 1.5 & & 0.63 \\
\hline & Hill 90-Hollomon & 1.83 & & 0.96 \\
\hline & Corus-Vegter -Bergström van Liempt & 1.52 & & 0.65 \\
\hline & Barlat-Krupkowsky & 1 & & 0.13 \\
\hline & Barlat-Hollomon & 0.86 & & 0.01 \\
\hline
\end{tabular}


By analyzing results, it is possible to notice, that the numerical simulation is sufficiently accurate, and can be considered as valid. For illustration, in Table 10 proposal of the most suitable material models for each type category of a material is presented. It should be noted, that the result values for different material models had small differences. This is because the experiment was conducted in the closed tool where the amount of springback is lower than it is in free air bending. Results of numerical simulation also had small differences using different material models.

Table 10. The most appropriate material models for each category of the material

\begin{tabular}{|c|c|c|}
\hline Category of material & Yield function & Hardening curve \\
\hline AHSS & Hill 90 & Krupkowsky, Hollomon \\
\hline UHSS & Hill 90 & Hollomon \\
\hline DC06 & Barlat & Hollomon \\
\hline
\end{tabular}

In the previous chapter it was mentioned that, the device measuring the contact force was located on the punch in order to measure the contact force among the punch and specimen. Graphical illustration was created from measured values. PAM-STAMP $2 \mathrm{G}$ include this option too. In order to complete the relevance of numerical simulation results, comparison of contact force progress of simulation and real experiment was created. The comparison of each progress for AHSS is presented in Fig. 5.

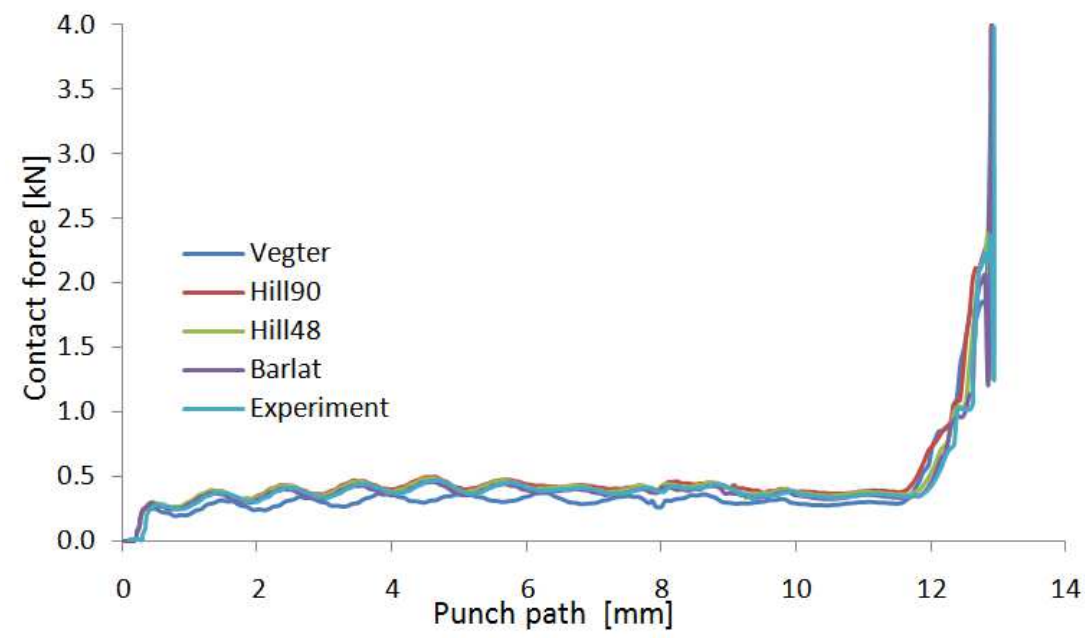

Fig. 5. Measured contact forces of the real experiment where AHSS steel was used and numerical simulations of following material models: Barlat, Hill 48 Hill 90 combined with Krupkowsky hardening curve and Vegter combined with Bergström van Liempt hardening curve 
Resulting from graphical illustration it can be noticed, that the size of contact force is approximately the same in each case - numerical simulation and real experiment. More important is that the graphical illustration proves high conformity of numerical simulation in comparison with the real experiment. The curves are wavy because specimen was sliding on the bending edge of die. Since the amount of springback is sensitive to size of contact force, great attention was given to not exceed maximum contact force of $4 \mathrm{kN}$.

In order to determine the distribution of stresses in the specimen, upper and lower major stresses along the sample length have been measured in the PAMSTAMP 2G software. Figures 6-8 illustrate, that the highest stresses occurred in the area, where the sheet metal is in contact with the die and the punch. The springback intensity is influenced by the distribution of different stresses in different areas of the part. Therefore, the closing force has a significant influence on the springback amount.

After the punch is removed, grains in neutral layer which are deformed mostly in the elastic domain are trying to orient on their initial position. During this process, the shape of the part is changed under the influence of phenomena called elastic springback. The strength of material has a significant influence on the springback amount. The higher strength has the material, the higher amount of springback occurs. TRIP steel has the highest strength, also higher springback in comparison with AHSS and mild steel was observed.

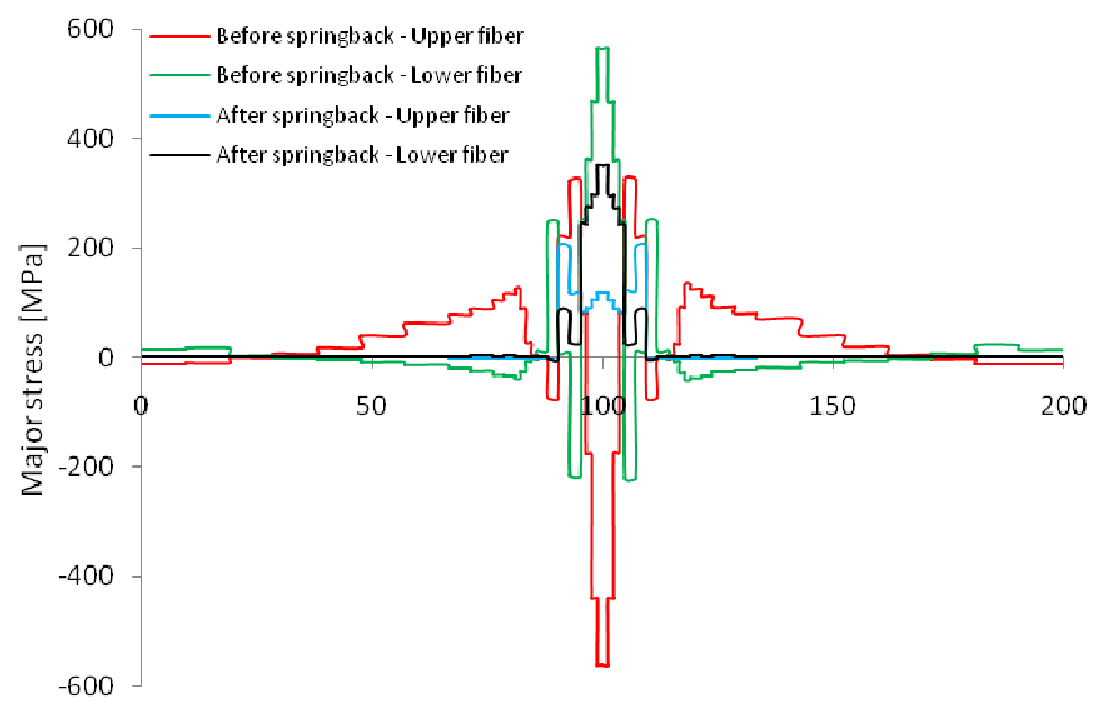

Fig. 6. Major stress distribution in the AHSS specimen 


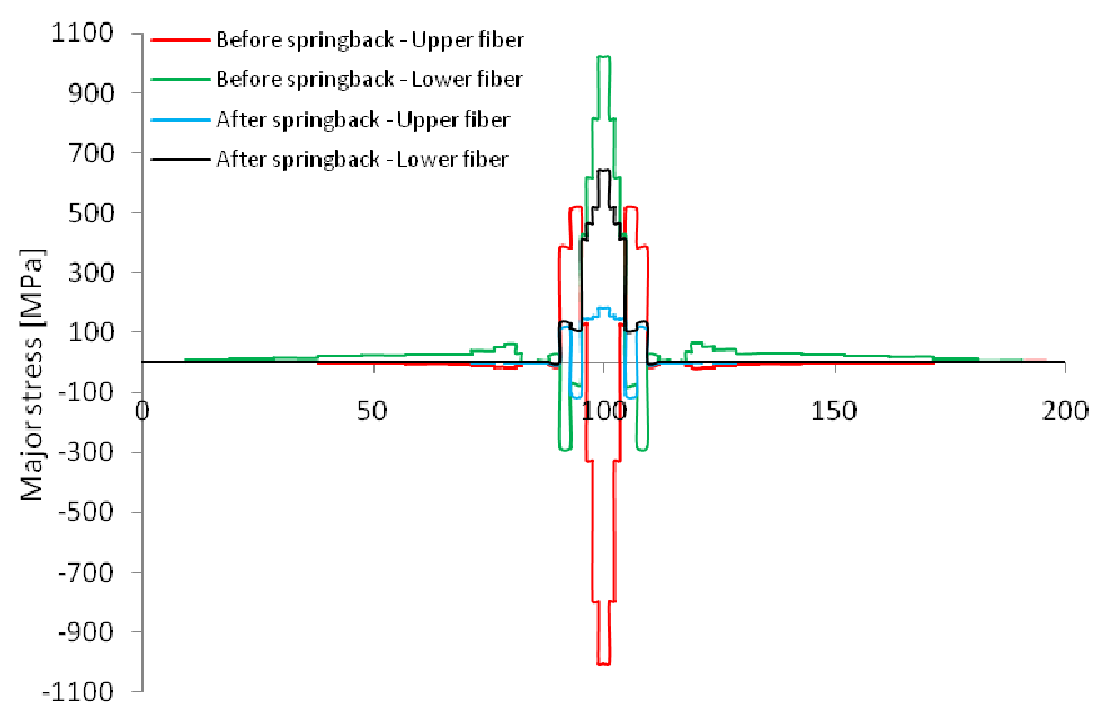

Fig. 7. Major stress distribution in the UHSS specimen

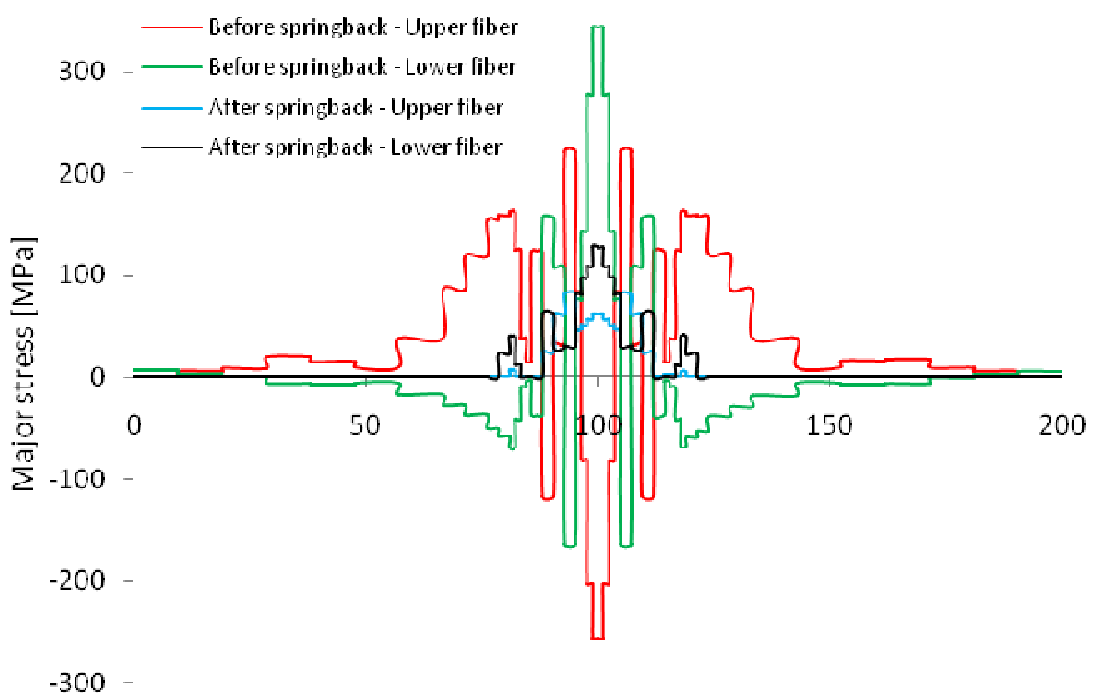

Fig. 8. Major stress distribution in the mild steel specimen

\section{Conclusion}

In this article, the manner of springback prediction in V-bending was described. Results of each experiment are presented in previous chapters. 
FE simulations of specimen made of AHSS were very close to real values of the springback amount. Using Hill 90 yield function combined with Krupkowsky and Hollomon hardening curve, the results varied only about $0.02^{\circ}$ and $0.06^{\circ}$. That is a deviation about maximum of $6 \%$.

Barlat and Hill 90 yield function combined with Hollomon hardening curve are the most suitable for the material from UHSS. The results of FE simulation and real experiment varied at $0.02^{\circ}$.

Last used material, mild steel DC06, Barlat yield function and Hollomon hardening curve was the most accurate, because results varied at $0.01^{\circ}$. In this case, also Hill 48 - Krupkowsky material model and Barlat - Krupkowsky were close to experimental results of the angle of springback. Deviation could be caused by the definition of the yield function that is not accurate enough.

The higher strength of the material is, the higher springback occurs. UHSS TRIP steel has the highest springback, then AHSS, and the smallest springback was observed in specimen made of mild steel.

Closing force has a significant influence on the amount of the springback, because in the place where the blank is in contact with the tool, there are the highest stresses. For more accurately results of numerical simulation, the next challenge will be improving the definition of material models. The conditions of the bending process are not static, and that is why the results could be softly distorted so, using kinematic hardening of materials seems to be substantiated. The future challenges are, for example: more accurately defining the Bauschinger effect, assuming imperfect - elastic behavior of the tool, taking into consideration unloading velocity, the temperature effect etc.

\section{References}

[1] Ashby M.F.: Materials selection in mechanical design, $2^{\text {nd }}$ ed., ButterworthHeinemann, Oxford 1999.

[2] Pearce R.: Sheet metal forming, Adam Hilger, UK 1991.

[3] Burchitz I.A.: Improvement of springback prediction in sheet metal forming, Universiteit Twente The Netherlands, 2008.

[4] Marciniak Z., Duncan J.L., Hu S.J.: Mechanics of sheet metal forming, London 2002.

[5] Gan W., Wagoner R.H.: Die design method for sheet springback, Int. J. Mech. Sci., 46 (2004), 1097-1113.

[6] Garcia-Romeu M.L., Ciurana J., Ferrer I.: Springback determination of sheet metals in an air bending process based on an experimental work, J. Mat. Proc. Technol., 191 (2007), 174-177.

[7] Lange K., Pohlandt P.: Handbook of metal forming, McGraw-Hill, New York 1985.

[8] Dallas D.B.: Society of manufacturing engineers and american society of tool and manufacturing engineers, tool and manufacturing engineers handbook: A reference work for manufacturing engineers, McGraw-Hill, New York 1976. 
[9] Sachs G.: Principles and methods of sheet-metal fabricating, Reinhold Pub., New York 1951.

[10] Livatyli H., Altan T.: Prediction and elimination of springback in straight flanging using computer aided design methods: Part I. Experimental investigations, J. Mat. Proc. Technol., 119 (2001), 117-262.

[11] Ling Y., Lee H., Cheok B.: Finite element analysis of springback in L-bending of sheet metal, J. Mat. Proc. Technol., 159 (2005), 296-302.

[12] Gau J.T., Kinzel G.L.: A new model for springback prediction in which the Bauschinger effect is considered, Int. J. Mech. Sci., 43 (2001), 1813-1832.

[13] Gau J.T., Kinzel G.L.: An experimental investigation of the influence of the Bauschinger effect on springback predictions, J. Mat. Proc. Technol., 119 (2001), 369-375.

[14] Albut A., Brabie G.: The influence of the rolling direction of the joined steelsheets on the springback intensity in the case of $\Omega$-shape parts made from tailor welded strips, Arch. Civil Mech. Engn., 6 (2006), 5-12.

[15] Gomes C. et.al: Investigation of springback in high strength anisotropic steels, J. Mat. Proc. Technol., 159 (2005), 91-98.

[16] Roll K.: Simulation of sheet metal forming - developments in the future, Bamberg 2008.

[17] Frącz W., Stachowicz F.: Springback phenomenon in sheet metal V-die air bending experimental and numerical study, Manuf. Industrial Engn., 7 (2008), 34-37.

[18] Hollomon J.H.: The effect of heat treatment and carbon content on the work hardening characteristics of several steels, Trans. ASM, 32 (1944), 123.

[19] Krupkowski A.: The deformation of plastic metals by strain, Ann. Acad. Pol. Sci. Technol., 7 (1946) 113-118.

[20] Vegter H. et.al.: Characterization and modeling of the plastic material behavior and its application in sheet metal forming simulation, VII Int. Conf. Computational Plasticity, Corus Research Development \& Technology, 2003.

[21] Pam-Stamp 2G 2009 - User`s guide, (C) 2009 ESI Group.

[22] Banabic D.: Sheet metal forming processes, constitutive modeling and numerical simulation, Springer, Berlin 2010.

[23] Atzema E., Abspoel M. et.al.: Towards robust simulations in sheet metal forming, TATA Steel Co.

[24] Andersson A.: Numerical and experimental evaluation of springback in a front side member, J. Mat. Proc. Technol., 169 (2005), 352-356.

[25] Fei D., Hodgson P.: Experimental and numerical studies of springback in air Vbending process for cold rolled TRIP steels, Nuclear Engn. Design, 236 (2006), 1847-1851.

[26] Kardes Sever N. et.al.: Springback prediction in bending of AHSS-DP-780, Proc. NAMRI/SME, vol. 40, The Ohio State University, USA 2012.

This contribution is the result of the projects implementation: Center for research of control of technical, environmental and human risks for permanent development of production and products in mechanical engineering (ITMS: 26220120060) supported by the R\&D Operational Programme funded by the ERDF and VEGA 1/0396/11. 


\section{EKSPERYMENTALNE I NUMERYCZNE PRZEWIDYWANIE ODKSZTAŁCEŃ SPRĘŻYNOWANIA W PROCESIE WYGINANIA BLACH ANIZOTROPOWYCH DLA PRZEMYSEU SAMOCHODOWEGO}

Streszczenie

Sprężynowanie jest powszechnym zjawiskiem występującym podczas kształtowania blach spowodowanym zmianą rozkładu naprężeń po zdjęciu obciążenia. Zauważono, że znajomość sprężynowania jest istotna $\mathrm{w}$ projektowaniu narzędzi używanych podczas operacji kształtowania blach. Program oparty na metodzie elementów skończonych (MES) został wykorzystany do analizy procesu wyginania. W badaniach wykorzystano blachy stalowe TRIP, AHSS i blachy ze stali miękkiej. Uwzględniono anizotropię normalną materiałów blach. Algorytm kontaku dla sztywnych narzędzi o dowolnym kształcie został zrealizowany za pomocą podejścia ścisłego. $\mathrm{W}$ artykule opisano metodę przewidywania sprężynowania podczas gięcia i odciążania blach. Omówiono modele konstytutywne ukierunkowane na przewidywanie końcowego kształtu blachy po sprężynowaniu, przy zróżnicowanych parametrach procesu kształtowania. Dokładność modelu została zweryfikowana przez porównanie wyników obliczeń $\mathrm{w}$ programie PAM-STAMP 2G $\mathrm{z}$ wynikami eksperymentalnymi.

Słowa kluczowe: gięcie swobodne, sprężynowanie, anizotropia plastyczna, modelowanie numeryczne

DOI: $10.7862 / \mathrm{rm} .2012 .5$ 